\title{
Collembola of North Bull Island - new records for the Irish coast
}

\author{
Maria STERZYŃSKA* and Thomas BOLGER** \\ **Museum and Institute of Zoology Polish Academy of Sciences, 00-679 Warsaw, Wilcza 64, Poland \\ e-mail:majka@miiz.waw.pl \\ **Department of Zoology University College Dublin, Belfield, Dublin 4 \\ e-mail:tom.bolger@ucd.ie
}

\begin{abstract}
A study of the Collembola from the marine littoral habitats on North Bull Island, which is a nature Man and the Biosphere Nature Reserve in Ireland, revealed 43 species of which 9 are new to the Irish fauna. Several rare species, known only from a few localities in Europe, Willemia multilobata, Friesea cf. baltica, Protaphorura pseudocellata and Isotomodes sotoensis were found.
\end{abstract}

Key words: Collembola, marine littoral habitats, Irish seashore

\section{INTRODUCTION}

Wetlands and sandy soils are important from a conservation point of view. This is particularly so in Ireland, yet with the exception of a study by Healy (1975) and, to a certain extent, Purvis (1982), very little is known of the collembolan fauna of such systems. This paper reports on a faunistic study of the Collembola of some coastal habitats in Ireland.

Collembola are common in the marine littoral environment. In such habitats many ecological factors, such as salinity, food, wave action, sand-grain angularity, can determine the distribution and species compositon of Collembola (Joosse 1976, Christian 1989, Hopkin 1997). In Europe, the coasts of the Baltic Sea, North Sea, Western Mediterranean Sea and Adriatic shores have been well studied (Christian 1989, Sterzyńska \& Ehrnsberger 1997) but the current knowledge on the distribution and biogeography of Collembola in the marine littoral zone is still fragmentary and insufficient.

The main goal of this work is to describe some new records of Collembola from the Irish coast and to review the present knowledge of the marine littoral Collembola from Ireland.

\section{STUDY SITES}

The investigations were carried out in nature reserve on North Bull Island, Dublin Bay. The North Bull Island Nature Reserve lies in the estuary of River Liffey and vegetation complexes, characteristic of European shorelines near river mouths, have developed (Jeffery et al. 1977). During the study two major habitats: a dune complex and a salt marsh with two zones: intertidal and supralittoral were sampled.

\section{MATERIAL AND METHODS}

Material was collected during 1995-2002 using commonly accepted quantitative methods (10 soil cores with diameter of $5.5 \mathrm{~cm}^{2}$ to $10 \mathrm{~cm}$ depth). Additionally, the qualitatively samples from different type of marine algae wrack accumulations and sandy dune habitats were taken. All the material was extracted in Macfadyen high gradient apparatus excepts, samples from sandy habitats where floatation was used and specimens were up from the water surface under stereomicroscope. 


\section{RESULTS AND DISCUSSION}

43 Collembola species were found in the littoral and supralittoral zones of the North Bull Island (Table 1).

Table 1. Check list of Collembola of the marine littoral habitats, North Bull Island Reserve. Species marked with an asterisk $(*)$ are firstly recorded for Irish coast and those marked with two asterisks $(* *)$ are new records for Ireland according to Bolger (1986).

\begin{tabular}{|c|c|c|c|}
\hline \multirow{2}{*}{ No. } & \multirow{2}{*}{ Occurrence of species } & \multicolumn{2}{|c|}{ Type of habitat } \\
\hline & & Salt marsh & Dune complex \\
\hline 1 & 2 & 3 & 4 \\
\hline & Hypogastruridae & & \\
\hline 1 & Ceratophysella denticulata (Bagnall, 1941) & + & \\
\hline 2 & Willemia multilobata Gers \& Deharveng, $1985^{* *}$ & + & \\
\hline 3 & Xenylla grisea Axelson, 1900* & & + \\
\hline 4 & Xenylla maritima Tullberg, 1869 & + & \\
\hline & Neanuridae & & \\
\hline 5 & Brachystomella parvula (Schäffer, 1896)* & & + \\
\hline 6 & Friesea mirabilis (Tullberg, 1871) & + & \\
\hline 7 & Friesea truncata Cassagnau, $1958^{* *}$ & + & \\
\hline 8 & Friesea cf. baltica Szeptycki, 1967** & & + \\
\hline 9 & Micranurida pygmaea Börner, 1901* & + & \\
\hline 10 & Anurida maritima (Guérin, 1839) & & \\
\hline & Onychiuridae & & \\
\hline 11 & Protaphorura armata (Tullberg, 1869) Gisin, 1960 & + & \\
\hline 12 & Protaphorura pseudocellata (Naglitsh, 1962)* & + & \\
\hline 13 & Protaphorura sp. & + & \\
\hline 14 & Thalassophorura debilis (Moniez, 1890) & + & \\
\hline 15 & Onychiurus ambulans (Linnaeus, 1758) sensu Stach, 1934* & & + \\
\hline 16 & Mesaphorura pongei Rusek, $1982^{* *}$ & + & + \\
\hline 17 & Mesaphorura petterdassi (Fjellberg, 1988)** & + & + \\
\hline 18 & Mesaphorura critica Ellis, 1976** & & + \\
\hline 19 & Mesaphorura krausbaueri Börner, 1901 & + & + \\
\hline 20 & Mesaphorura macrochaeta Rusek, 1979** & + & + \\
\hline 21 & Mesaphorura sp. & + & \\
\hline & Isotomidae & & \\
\hline 22 & Hemisotoma thermophila (Axelson, 1900)* & & + \\
\hline 23 & Folsomia quadrioculata (Tullberg, 1871)* & + & \\
\hline 24 & Folsomia sexoculata (Tullberg, 1871) & + & \\
\hline 25 & Archisotoma sp.* & + & \\
\hline 26 & Isotomodes sotoensis Simon et. al., 1994* & & + \\
\hline 27 & Isotoma anglicana Lubbock 1862* & + & + \\
\hline 28 & Isotoma viridis Bourlet, 1839 & + & \\
\hline 29 & Halisotoma maritima Tullberg, 1871 & + & \\
\hline 30 & Parisotoma notabilis (Schäffer, 1896)* & + & \\
\hline 31 & Desoria tigrina $(\text { Nicolet, } 1842)^{* *}$ & + & \\
\hline 32 & Desoria sp.* & + & \\
\hline 33 & Isotomurus palustris (Müller, 1776)* & + & \\
\hline & Tomoceridae & & \\
\hline 34 & Pogonognathellus longicornis (Müller, 1776)* & + & \\
\hline
\end{tabular}




\begin{tabular}{|c|l|c|c|}
\hline 1 & \multicolumn{1}{|c|}{2} & 3 & \\
\hline & \multicolumn{1}{|c|}{ Entomobryidae } & & \\
35 & Entomobrya lanuginosa (Nicolet, 1841)* & + & \\
36 & Lepidocyrtus cyaneus Tullberg, 1871* & + & \\
37 & Lepidocyrtus lignorum (Fabricius, 1775)* & + & \\
& Sminthuridae & + & \\
38 & Sphaerida pumilis (Krausbauer, 1898)* & + & \\
40 & Dicyrtomina minuta (O.Fabricius, 1783)* & + \\
41 & Dicyrtomina ornata (Nicolet, 1841)* & + \\
43 & Sminthurinus aureus (Lubbock, 1862)* & \\
\hline
\end{tabular}

Healy (1975) studied Collembola of the marine littoral zone of the North Bull Island and she recorded only 9 species in the intertidal zone (Xenylla maritima, Friesea mirabilis, Anurida maritima, Thalassophorura debilis, Mesaphorura krausbaueri s. lato, Halisotoma maritima, Isotoma viridis, Isotomiella minor, Folsomia sexoculata). During recent studies in 1995-2002, the a further 36 species were recorded (Table), including 9 species new to Ireland. Some of them are known only from a few localities in Europe: Willemia multilobata, Friesea baltica, Protaphorura pseudocellata or from type locality Isotomodes sotoensis.

The majority of species in the marine littoral habitats of North Bull Island are typical representatives of coastal habitats (seashore dwellers). The intertidal zone and in supralittoral dunes are habitats for intertidal species (Halisotoma maritima, Folsomia sexolculata, Thalassophorura debilis, Archisotoma sp.) and interstitial species (Friesea baltica, Mesaphorura pongei, M. petterdassi, M. critica, Hemisotoma thermophila, Isotomodes sotoensis). From a biogeographic viewpoint the following records are of special importance:

Willemia multilobata Gers \& Deharveng, 1985. This species has only been recorded from a single location in Denmark where it was found in grazed dry meadows (Fjellberg, 1998). In Ireland we found it in wrack material in the intertidal zone.

Friesea cf baltica Szeptycki, 1967. This species was described from the Baltic seashore (Poland) by Szeptycki (1964). There are only a few records from Denmark and the southern coasts of Norway and Sweden (Fjellberg, 1998). The species is found in sandy meadows and dunes along the seashore. In Ireland it was recorded from a dune complex ${ }^{1}$.

Protaphorura pseudocellata (Naglitsh, 1962). This species has been reported from Poland and Germany. P. pseudocellata dwells in warm, dry sandy places in mountains, highlands and lowlands. It has been collected in sandy dune near see shore, in sandy soil covered limestone rocks and in dry soil with roots of grass and other plants (Pomorski, 1998). In Ireland we recorded it from salty meadows in the intertidal zone on Bull Island Reserve.

Mesaphorura pongei Rusek, 1982. This has been recorded from Denmark and the southern parts of Sweden and Norway. It commonly dwells in sandy dunes and sea meadows with Ammophila arenari and Elymus arenarius. In Ireland it was recorded from fixed dunes with plant communities Tortulo-Phleetum plant communities and from wrack material.

Mesaphorura petterdassi (Fjellberg, 1988). Fjellberg (1998) classified this as a widely distributed species, recorded from meadows and forest soils, in Norway, often collected in damp habitats alongside inland lakes and streams. On North Bull Island it was found in the low

\footnotetext{
${ }^{1}$ The species found on the Irish coast differ from the material described originally in the chaetotaxy of Th. 3-4, where the $\mathrm{m}_{4}$ chaeta is present and on Abd 4 chaeta $\mathrm{a}_{2}$ is present.
} 
intertidal zone with plant communities Juncetum gerardii and in dune complex where TortuloPhleetum plant communities occur.

Isotomodes sotoensi (Simon et al., 1994). This species has only been previously recorded from its type locality (Potapow, 2001). On North Bull Island it was found in supralittoral zone on the primary dune ridge colonised by Ammophila arenaria and Elymus arenarius.

\section{ACKNOWLEDGEMENTS}

This study would not have been possible without the financial assistance received from the Polish Academy of Sciences, The Royal Irish Academy and a Wildlife Grant from The Heritage Council in Ireland.

\section{REFERENCES}

Bolger T. 1986. The Collembola of Ireland - A check list and bibliography. Proceedings of the Royal Irish Academy, Section B 86, B, 8: 184-218.

CHRISTIAN E. 1989. Biogeography, substrate preference, and feeding types of North Adriatic intertidal Collembola. Marine Ecology 10: 79-94.

Fjellberg A. 1998. The Collembola of Fennoscandia and Dennmark. Part I: Poduromorpha. Fauna Entomologica Scandinavica 35: 1-184.

HEALY B. 1975. Fauna of the salt-marsh, North Bull Island, Dublin. Proceedings of the Royal Irish Academy 75, B, 10: $225-244$.

HOPKIN S.P. 1997. Biology of the springtails. Insecta: Collembola. Oxford University Press, 330 pp.

JefFery D. W., Goodwillie R. N., Healy B., Holland C. H., JaCkson J. S., Moore J. J. 1977. North Bull Island Dublin Bay - a modern coastal natural history. The Royal Dublin Society.

JoossE E.N.G. 1976. Littoral apterygotes (Collembola and Thysanura), pp 151-186. In: Cheng L (ed.), Marine insects. North -Holland Publ. Comp. (N.Y.).

POMORSKI J. R. 1998. Onychiurinae of Poland (Collembola:Onychiuridae). Genus, 201 pp.

POTAPOw M. 2001. Synopsis on Palearctic Collembola. Isotomidae. Abh. Ber. Naturkundemus Görlitz 73 : 1-603.

PURVIS G. 1982. The soil arthropod fauna (Acari and Collembola) of a coastal location in southeast Ireland. Journal of the Life Sciences of the Royal Dublin Society 3, 379-386.

STERZYNSKA M., EHRnSBERGER R. 1997. Marine algae wrack Collembola of European coasts. Abh. Ber. Naturkunemus. Görlitz 69: 165-178.

SZEPTYCKI A. 1964. Two new species of Collembola from Wolin Island (north-west Poland). Bulletin Entomologique de Pologne 34, 5, 172-176.

\section{STRESZCZENIE}

\section{[Collembola rezerwatu biosfery "North Bull Island" - nowe stwierdzenia dla wybrzeży morskich Irlandii]}

W trakcie badań faunistycznych rezerwatu „North Bull Island” położonego w ujściu rzeki Liffey do zatoki Dublińskiej (Irlandia) stwierdzono występowanie 43 gatunków Collenbola, w tym 9 gatunków nowych dla fauny Irlandii. Praca zawiera wykaz gatunków dotychczas stwierdzonych w zalewanej strefie litoralowej i supralitoralowej oraz komentarz do gatunków cennych z punktu widzenia zoogeografii, m. innymi: Willemia multilobata, Friesea cf. baltica, Protaphorura pseudocellata, Mesaphorura pongei, M. petterdassi and Isotomodes sotoensis. 